Silvertown, J. (1987): Introduction to Plant Population Ecology. Longman Scientific \& Technical Essex, England.

TURKINGTON, R. (1989): The growth, distribution and neighbour relationships of Trifolium repens in a permanent pasture. V. The coevolution of competitors. J. Ecology 77, 717-733.

Turkington, R. and L. W. AARssen (1984): Local-scale differentiation as a result of competition. In: DIRZO, R. SARUkHAN, J. (eds.). Perspectives in Plant Population Ecology. Sinauer Associates, Cambridge, Mass., pp. 107-127.
VAVREK, M. C. (1998): Within-population genetic diversity of Taraxacum officinale (Asteraceae). Differential genotype response and effect on interspecific competition. Amer. J. Botany 85, 947-954.

Wehenkel, C., F. Bergmann and H. R. Gregorius (2006): Is there a trade-off between species diversity and genetic diversity in forest tree communities. Plant Ecology 185, 151-161.

WENDEL, J. F. and N. F. WEEDEN (1989): Visualization and interpretation of plant isozymes. In: Soltis, D. E., Soltis, P. S. (eds.). Isozymes in Plant Biology. Chapman and Hall, London, pp. 5-45.

\title{
Results of an International Provenance Trial of Cordia alliodora in São Paulo, Brazil at Five and 23 Years of Age
}

\author{
By A. M. Sebbenn ${ }^{1), 2)}$, D. H. BoshieR ${ }^{3)}$, M. L. M. Freitas ${ }^{4)}$, A. C. S. Zanatto ${ }^{4)}$, \\ A. S. SATO ${ }^{4)}$ L. C. EtTori ${ }^{4)}$ and E. Moraes ${ }^{4)}$
}

(Received $8^{\text {th }}$ February 2006)

\begin{abstract}
Cordia alliodora (Ruiz \& Pav.) Oken (Boraginaceae) is a tropical timber tree of great economic value that occurs in Latin America and through most of the Caribbean. Genetic variation in growth, form and survival of eight Central America provenances - five from a dry zone and three from a wet zone - were studied five and 23 years after establishment in the state of São Paulo, Brazil. Significant differences between dry and wet zone provenances were detected for diameter at breast height (d.b.h.), stem form and survival and between provenances within these zones for height, d.b.h., volume and survival. Provenances from the dry zone had higher growth rates than those from the wet zone. Genetic correlations among ages for these traits were positive but not significant, while ranking of provenances based on growth and survival changed significantly from five to 23 years of age, indicating that measuring traits at five years of age may not be a good predictor of the same traits at 23 years of age. Genetic correlations on growth traits measured at the same age were large and significant, suggesting substantial gains could be made through indirect trait selection. At 23 years of age the La Fortuna provenance performed best for all traits, while Nueva Guinea performed worst for growth traits and survival and Tres Piedras for stem form. The species' poor growth compared to that of other

\footnotetext{
1) Bundesforschungsanstalt für Forst- und Holzwirtschaft (BHF), Institut für Forestgenetik und Forstpflanzenzüchtung, Sieker Landstrasse 2, D-22927, Grosshansdorf, Germany.

2) Corresponding author: Present full address: Instituto Florestal de São Paulo, Caixa postal 1322, 01059-970, São Paulo. E-mail alexandresebbenn@yahoo.com.br.

3) Oxford Forestry Institute, Dept. Plant Sciences, South Parks Road, Oxford, OX1 3RB, UK.

$\left.{ }^{4}\right)$ Adress see ${ }^{2}$ ).
}

tropical tree species at the same experimental site suggests that $C$. alliodora is not the best silvicultural option for the Luiz Antonio region.

Key words: Tropical tree species, genetic structure, genetic correlations, tree improvement.

\section{Introduction}

Cordia alliodora (Ruiz \& Pav.) Oken (Boraginaceae) is a well known timber tree in tropical zones of Latin America and most of the Caribbean (BoshIER and MESÉn, 1987). It is a medium to large-sized, hermaphroditic, insect-pollinated, outcrossing tree with a widespread distribution from northern Mexico $\left(25^{\circ} \mathrm{N}\right)$ through Central and South America as far south as Bolivia, southern Brazil, and northern Argentina (25 $\mathrm{S}$ ) (CHASE et al., 1995; Boshier et al., 1995; BoshIER and LAMB, 1997). Its precise range in southern South America is uncertain due to taxonomic confusion with the closely related C. trichotoma (Vell.) Arrab. Ex Steud. (GIBBS and TARODA, 1983). It is also found on most of the Caribbean Islands from Cuba to Trinidad but is probably not native to Jamaica (CHASE et al., 1995). C. alliodora occurs under a wide variety of ecological conditions varying from very wet (as much as $6,000 \mathrm{~mm}$ rainfall per year) to seasonally dry (as low as $800 \mathrm{~mm}$ per year), and from sea level to as high as $1,400 \mathrm{~m}$ in Central America and $2,000 \mathrm{~m}$ at lower latitudes in Colombia (GREAVES and MCCARTER, 1990). In lowland areas of moderate to high rainfall, trees can reach over $40 \mathrm{~m}$ in height and over $80 \mathrm{~cm}$ in diameter at breast height. In contrast, in dry regions trees are generally small (10-15 $\mathrm{m}$ in height) and of poor form (GREAVES and MCCARTER, 1990; CHASE et al., 1995). In general, the provenances 
from the Caribbean watershed of Honduras, Nicaragua and Costa Rica show the best growth and form in tropical regions (LiEgel and STEAD, 1990; BoshieR and HENSON, 1997).

C. alliodora is an important pioneer neotropical tree that combines high quality timber with fast growth in good soils (BosHIER and LAMB, 1997). The species is frequently used in coffee and cacao agroforestry systems for shade (YARED, 1993; BOSHIER and LAMB, 1997; LIEGEL and STEAD, 1990). It tolerates a range of climatic and edaphic conditions, but shows best growth at low altitudes with a moderately wet climate (BosHIER and LAMB, 1997; LIEGEL and STEAD, 1990). C. alliodora timber is durable, easy to work, highly resistant to insect attack and is widely used in carpentry, furniture, construction, flooring, decorative panels, etc. (YARED, 1993), aside from showing potential for paper and pulp production. Its timber proprieties are comparable to Swietenia macrophylla, Tectona grandis and Juglans regia, with good acceptance and prices in local markets (HUMMEL, 2001) as well as being the species with highest demand in the timber market of Costa Rica.

Given the high importance of this species to tropical regions, in 1977 the Oxford Forestry Institute initiated an international programme of provenance trials of C. alliodora from Central America in tropical countries across the world. Results from this international trial, comparing the performance of the dry and wet provenances in various countries (Costa Rica, Colombia, Fiji, Solomon, Ivory Coast, Liberia, Ghana and Nigeria), showed that provenances from wet zones had higher survival and quicker growth than dry zone provenances (Boshier and Henson, 1997). In contrast, at five years of age in provenance trials established at three sites in southern Brazil (Bebedouro, São José do Rio Preto and Luiz Antonio) dry zone provenances grew more than wet zone ones (BosHIER and HENSON, 1997). However, whereas the tropical sites had reached $1 / 3$ to $2 / 3$ rotation size at assessment, the Brazilian site results were only preliminary as growth was much slower. Recommendations of the best provenance for a particular environment require long term evaluation (ZOBEL and TALBERT, 1984).

This study is part of the international $C$. alliodora provenance trials, initiated in 1977 by the Oxford Forestry Institute (OFI), United Kingdom. In São Paulo State, Brazil, four trials were established: Bebedouro State Forest, Migi-Mirim, São José do Rio Preto and Luiz Antonio Experimental Station. The preliminary results at the age of five years were published by Boshier and Henson (1997). The Bebedouro, São José do Rio Preto and Mogi-Mirim trials were lost due to poor adaptation, fire and ant attack respectively. Here, we compare the results at five and 23 years of age for the Luiz Antonio trial. The specific objectives were to: $i$ ) study the genetic variation in C. alliodora provenances for the main silvicultural traits in the region of Luis Antonio - SP; ii) study the correlation between traits of growth and geographic and climatic features in the species' natural occurrence; iii) classify provenances according to their silvicultural performance; and $i v$ ) select superior trees for a base population to initiate a genetic improvement programme.

\section{Material and Methods}

\section{Provenances and experimental site}

Open pollinated seeds were collected from trees of the eight $C$. alliodora provenances in Central America by OFI. Bulk seed collections were made from 25 to 80 mother-trees (Table 1) sampled randomly in each population (STEAD, 1980). The mother-trees were separated by a minimum distance of $100 \mathrm{~m}$. The geographic and climatic characteristics of the provenances are in Table 1. These provenances were classified in dry and wet zones based on BosHIER and HENson (1997) studies.

The provenance trial was established at the Experimental station of Luiz Antonio (Lat. $21^{\circ} 40^{\prime} \mathrm{S}$, Long. $47^{\circ}$ $49^{\prime} \mathrm{W}$ and $550 \mathrm{~m}$ above sea level) in 1982. At the station the mean annual rainfall is $1,280 \mathrm{~mm}$ with about five months of water deficit and the soil is a Latosol (VENTURA et al., 1965/1966). The trial was established in a complete randomized block design with eight prove-

Table 1. - Number of trees from which seeds were collected, geographic coordinates, altitude, annual rainfall, number of dry months and temperature of the provenance sites of $C$. alliodora seed collections in Central America.

\begin{tabular}{|c|c|c|c|c|c|c|c|c|}
\hline OFI code & Provenance & $\begin{array}{l}\mathrm{N}^{\circ} \text { mother- } \\
\text { trees }\end{array}$ & $\begin{array}{c}\text { Latitude } \\
\mathrm{N}\end{array}$ & $\begin{array}{c}\text { Longitude } \\
\text { W }\end{array}$ & $\begin{array}{l}\text { Altitude } \\
\text { (m) }\end{array}$ & $\begin{array}{l}\text { Annual } \\
\text { rainfall } \\
(\mathrm{mm})\end{array}$ & $\begin{array}{c}\text { Number of dry } \\
\text { months } \\
(<70 \mathrm{~mm})\end{array}$ & $\begin{array}{c}\text { Temperature } \\
\left({ }^{\circ} \mathrm{C}\right) \\
\text { (annual mean) }\end{array}$ \\
\hline \multicolumn{9}{|c|}{ Dry zone } \\
\hline $10 / 77$ & Finca El Chilero (Guatemala) & 30 & $14^{\circ} 23^{\prime}$ & $90^{\circ} 28^{\prime}$ & 1,350 & 1,956 & 6 & 20.4 \\
\hline $30 / 78$ & Finca Rincón Alegre (Guatemala) & 25 & $14^{\circ} 27^{\prime}$ & $91^{\circ} 46^{\prime}$ & 120 & 1,524 & 3 & 26.1 \\
\hline $9 / 77$ & Três Piedras (Honduras) & $\sim 80$ & $13^{\circ} 02^{\prime}$ & $87^{\circ} 04^{\prime}$ & 110 & 1,850 & 6 & 27.8 \\
\hline $14 / 77$ & Esteli (Nicarágua) & 25 & $13^{\circ} 02^{\prime}$ & $86^{\circ} 19^{\prime}$ & 850 & 848 & 7 & 22.6 \\
\hline $18 / 77$ & Finca La Pineda (Nicarágua) & 25 & $12^{\circ} 45^{\prime}$ & $85^{\circ} 45^{\prime}$ & 750 & 1,374 & 6 & 23.2 \\
\hline \multicolumn{9}{|c|}{ Wet zone } \\
\hline $19 / 77$ & Finca La Fortuna (Honduras) & 25 & $15^{\circ} 36^{\prime}$ & $87^{\circ} 58^{\prime}$ & 210 & 1,373 & 5 & 25.6 \\
\hline $20 / 77$ & San Francisco (Honduras) & 25 & $15^{\circ} 40^{\prime}$ & $87^{\circ} 02^{\prime}$ & 50 & 2,858 & 0 & 23.7 \\
\hline $33 / 78$ & Nueva Guinea (Nicarágua) & 25 & $11^{\circ} 43^{\prime}$ & $84^{\circ} 26^{\prime}$ & 220 & 2,588 & 3 & 26.1 \\
\hline
\end{tabular}

The provenances were classified in dry and wet zones based on studies of BosHIER and Henson (1997). 
nances, four replications, twenty-five-tree square plots at $3 \times 2 \mathrm{~m}$ spacing, with two external border rows. The trial was assessed five and 23 years after planting for total tree height (h5, h23), diameter at breast height (d.b.h.5, d.b.h.23), volume (vl5, vl23) and survival (sur5, sur23). Individual tree volume with bark $\left(\mathrm{m}^{3}\right)$ was calculated using the formula,

$$
\begin{aligned}
v o l= & 0.017615+0.000034\left(d^{2} h\right)-0.000086\left(d^{2}\right)+ \\
& 0.003358 h(\text { SOMARRIBA and BEER, 1987) }
\end{aligned}
$$

where $d$ is the d.b.h., $h$ is the height. Stem form was also evaluated at 23 years of age (sf23), based on subjective criteria (ranging from one to five, considering the trunk straightness, bifurcations, lateral shoots and branches, where 1 is the worst and 5 the best grade). For analysis of variance the stem form and survival variables were transformed by $\sqrt{s f 23}$ and $\sqrt{s u r}$, respectively.

\section{Statistical analysis}

The analyses of variance for each trait and age were realized at the individual tree level, with the exception of survival that was evaluated on plot means. The analyses of variance for hierarchical structure of tree within provenance used the following statistical model:

$$
Y_{i j k}=m+b_{j}+t_{i}+e_{i j}+d_{i j k}
$$

where $Y_{i j k}$ is the phenotypic value of the $k^{\text {th }}$ individual of the $j^{\text {th }}$ block of the $i^{\text {th }}$ provenance; $m$ is the fixed effect of the general mean; $b_{j}$ is the fixed effect of the $j^{\text {th }}$ block; $t_{i}$ is the random effect of the $i^{\text {th }}$ provenance; $e_{i j}$ is the random effect of the interaction between the $i^{\text {th }}$ provenance and the $j^{\text {th }}$ block (error among); $d_{i j k}$ is the random effect of the error within the provenance; $j=1 \ldots . J, J=4$ ( $J$ is the number of blocks); $i=1 \ldots . . I, I=8$ ( $I$ is the number of provenances); $k=1 \ldots . . K$, ( $K$ is the number of trees per plot).

The following statistical model was used to verify if there were genetic differences among provenances from dry and wet zones and provenances within zone:

$$
Y_{i j k l}=m+b_{k}+z_{i}+t_{j(i)}+e_{j(i) k}+d_{i j k l}
$$

where $Y_{i j k l}$ is the phenotypic value of the $l^{\text {th }}$ individual of the $k^{\text {th }}$ block of the $j^{\text {th }}$ provenance of the $i^{\text {th }}$ zone; $m$ is the fixed effect of the general mean; $b_{k}$ is the fixed effect of the $k^{\text {th }}$ block; $z_{i}$ is the fixed effect of the $i^{\text {th }}$ zone; $t_{j(i)}$ is the random effect of the $j^{\text {th }}$ provenance within the $i^{\text {th }}$ zone; $e_{j(i) k}$ is the random effect of the interaction between the $j^{\text {th }}$ provenance within the $i^{\text {th }}$ zone and the $k^{\text {th }}$ block (error among); $d^{i j k l}$ is the random effect of the error within the provenance; where $i=1 \ldots . . I, I=2$ ( $I$ is the number of zones); $j=1 \ldots . . J, J=8$ ( $J$ is the number of provenances); $k=1 \ldots . K, K=4$ ( $K$ is the number of blocks); $l=1 \ldots . . l$, ( $J$ is the number of trees per plot).

$F$ tests of the analyses of variance were obtained using the GLM procedure of the statistical program SAS (SAS, 1989). Components of variance were estimated using the REML method (Restricted Maximum Likelihood) in combination with the VARCOMP procedure of SAS (SAS, 1989), as the experiment was unbalanced by the unequal tree survival per plot. Components of variance were estimated: $\sigma_{p}^{2}=$ genetic variance among provenances; $\sigma_{e}^{2}=$ environmental variance; $\sigma^{2}{ }_{w}=$ phenotypic variance within provenances. The genetic divergence among provenances was estimated as an intra-class correlation by,

$$
Q_{S T}=\sigma_{p}^{2} /\left(\sigma_{w}^{2}+\sigma_{e}^{2}+\sigma_{p}^{2}\right) .
$$

Genetic correlations $\left(r_{g}\right)$ between traits at the same and different ages were estimated using the equation:

$$
r_{g}=\sigma_{p x p y} / \sqrt{\sigma_{p x}^{2} \cdot \sigma_{p y}^{2}}
$$

where, $\sigma_{p x p y}$ is the genetic covariance of the traits $x$ and $y ; \sigma_{p x}^{2}$ and $\sigma_{p y}^{2}$ are the genetic variances among provenances for the traits $x$ and $y$, respectively. Genetic covariances were estimated from the analysis of covariance procedure in S.A.S. (S.A.S., 1989).

Genetic gains for each trait were estimated using a multi-effect selection index $\left(I_{m e}\right)$ derived by RESENDE (2002) that calculates the genetic value of each individual:

$$
\begin{aligned}
I_{m e}= & b_{11}\left(Y_{i j k}-\bar{Y}_{i j .}\right)+b_{12}\left(\bar{Y}_{i j .}-\bar{Y}_{i . .}-\bar{Y}_{. j .}+\bar{Y}_{\ldots}\right)+ \\
& b_{13}\left(\bar{Y}_{i . .}-\bar{Y}_{\ldots}\right),
\end{aligned}
$$

where, $Y_{i j k}, \bar{Y}_{i j}, \bar{Y}_{i . .}, \bar{Y}_{. j}$, and are the individual value, plot mean, provenance mean, block mean and general mean, respectively; the $b$ coefficients (coefficients of heritability, within provenances, within plots and average among provenances) were estimated by,

$$
\begin{aligned}
& b_{11}=\frac{\sigma_{a W}^{2}}{\sigma_{w}^{2}}=\frac{\left(1-\rho_{p}\right) h_{i}^{2}}{1-\rho_{p} h_{i}^{2}-c^{2}} \\
& b_{12}=\frac{\sigma_{a W}^{2} / n}{\left(\sigma_{w}^{2} / n\right)+\sigma_{e}^{2}}=\frac{\left(1-\rho_{p}\right) h_{i}^{2}}{1+(n-1) c^{2}-\rho_{p} h_{i}^{2}} \\
& b_{13}=\frac{\left(\sigma_{a W}^{2} / n b\right)+\sigma_{p}^{2}}{\left(\sigma_{w}^{2} / n b\right)+\left(\sigma_{e}^{2} / b\right)+\sigma_{p}^{2}}=\frac{\left[1+(n b-1) \rho_{p} h_{i}^{2}\right] h_{i}^{2}}{1+(n-1)\left(\rho_{p} h_{i}^{2}+c^{2}\right)+(b-1) n \rho_{p} h_{i}^{2}}
\end{aligned}
$$

were, $h_{i}^{2}$ is the heritability at an individual level. As this is a provenance trial it is not possible to estimate heritabilities, so these were inferred from BosHIER and HENSON (1997) who derived values for two provenances (San Francisco and San Carlos/Upala). The arithmetic means of these values were used for height $\left(h^{2}{ }_{i}=0.18\right)$ and d.b.h. $\left(h_{i}^{2}=0.135\right)$. For stem form the big value was used $\left(h^{2}{ }_{i}=0.06\right)$ and for volume we assumed a conservative value of 0.15 . The levels of these values are clearly conservatives; $\sigma_{a W}^{2}$ is the additive genetic variance within provenances; $\rho_{p}$ is covariance among individuals or coefficient of correlation (relatedness) between individuals from different families within provenances $\left(\rho_{p}\right)$, estimated by,

$$
\rho_{p}=h_{E}^{2} / h^{2}
$$

where, $h_{E}^{2}$ is the intra-class correlation between individuals from the same provenance or genetic divergence among provenances or the coefficient of "heritability" among provenances, estimated by,

$$
h_{E}^{2}=Q_{S T}=\sigma_{p}^{2} /\left(\sigma_{w}^{2}+\sigma_{e}^{2}+\sigma_{p}^{2}\right)
$$


$c^{2}=\sigma_{e}^{2} /\left(\sigma_{w}^{2}+\sigma_{e}^{2}+\sigma_{p}^{2}\right)$ is the intra-class correlation due to common plot environmental variation; $h^{2}$ the within family heritability. Since there are no published values of $h_{w}^{2}$ for C. alliodora and as all additive genetic variance among and within provenances $\left(h^{2}{ }_{a}\right)$ can be defined by $\sigma^{2}{ }_{a}=\sigma^{2}{ }_{a E}+\sigma^{2}{ }_{a W}$, consequently, $h_{i}^{2}=h_{E}^{2}+h^{2}{ }_{w}$, and thus, $h^{2}{ }_{w}{ }^{a}=h^{2}{ }_{i}+h_{E}{ }_{E} ; n$ is the mean number of trees per plot; $b$ is the repetition number.

Best trees were selected using an intuitive multi-trait index,

$$
I_{S}=x_{h} I_{h}+x_{d b h} I_{d b h}+x_{s f} I_{s f}+x_{v o l} I_{v o l},
$$

where, $I_{h}, I_{d b h}, I_{s f}$, and $I_{v o l}$ are the individual multi-effect index for height, d.b.h., stem form and volume, respectively; $x_{h}, x_{d b h}, x_{s f}$ and $x_{v o l}$ are weights of the traits height, d.b.h., stem form and volume, respectively. The highest weight was assigned to stem form (0.4) to improve stem form of the population. Height, d.b.h. and volume were given the same weight, 0.20 . Based on this index, the phenotypic value of the trees was determined as well as the trees to be selected to compose the breeding population.

Mean genetic gain $\left(G_{S}\right)$ to each trait was given by the arithmetic mean of individual genetic values of the selected trees,

$$
G s=\frac{\sum_{i=1}^{n_{s}} I_{m e}}{n_{s}},
$$

where, $i$ is a selected tree and $n_{s}$ is the number of selected trees. The gains were estimated for mass selection of the 150 best trees (34\% of trees) of the trial at 23 years of age, to maintain a high effective population size in the breeding population. The response to selection in percentage $[G s(\%)]$ was calculated by, $G s(\%)=$ $(G s / \bar{x}) .100$, where $\bar{x}$ is the trait mean.

\section{Results and Discussion}

\section{Genetic variation among and within zones and provenances}

The analysis of variance showed significant $(\mathrm{P}<0.01)$ differences among provenances for all evaluated traits and ages, with the exception of survival at 5 years of age (Table 2). As C. alliodora appears to show ecotypic differentiation between dry and wet climates in Central America (Boshier and Henson, 1997) we tested the hypothesis that there are differences in the performance of provenances from these different zones. The $F$ test revealed significant differences between dry and wet zone provenances for height, d.b.h. and volume at five years of age and for d.b.h. and stem form at 23 years of age and among provenances within zones for all traits, with the exception of survival at 5 years of age and stem form (Table 2). These results suggest that there is the possibility of increasing yield through selection of the more productive provenances.

The estimate of the genetic divergence among provenances $\left(Q_{S T}\right.$, Table 2$)$ for growth and form traits ranged from 0.051 (sf23) to 0.115 (h5), indicating that the largest part of genetic variation is found within provenances. A similar pattern of genetic divergence was observed by CHASE et al. (1995) in studying allozyme

Table 2. - Estimates of means ( \pm standard error), mean squares, $F$ test results and components of variance for height (h5, h23),

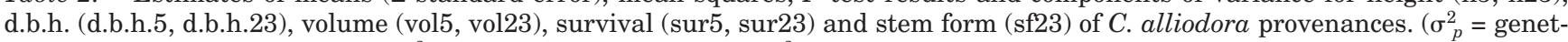
ic variance among provenances; $\sigma_{e}^{2}=$ environmental variance; $\sigma_{d}^{2}=$ phenotypic variance within provenance; $Q_{S T}=$ genetic diver-

\begin{tabular}{|c|c|c|c|c|c|c|c|c|c|}
\hline Provenance & $\begin{array}{l}\mathrm{h} 5 \\
(\mathrm{~m})\end{array}$ & $\begin{array}{l}\text { h23 } \\
(\mathrm{m}) \\
\end{array}$ & $\begin{array}{c}\text { d.b.h.5 } \\
(\mathrm{cm})\end{array}$ & $\begin{array}{c}\text { d.b.h.23 } \\
(\mathrm{cm})\end{array}$ & $\begin{array}{c}\text { vol5 } \\
\left(\mathrm{m}^{3} / \text { tree }\right)\end{array}$ & $\begin{array}{c}\text { vol23 } \\
\left(\mathrm{m}^{3} / \text { tree }\right)\end{array}$ & $\begin{array}{l}\text { sur5 } \\
(\%)\end{array}$ & $\begin{array}{c}\text { sur23 } \\
(\%)\end{array}$ & sf23 \\
\hline \multicolumn{10}{|l|}{ Dry zone } \\
\hline Finca El Chilero & $5.00 \pm 0.17$ & $8.23 \pm 0.30$ & $6.27 \pm 0.27$ & $11.22 \pm 0.50$ & $0.034 \pm 0.0006$ & $0.045 \pm 0.0010$ & 73.8 & 65.0 & $1.90 \pm 0.09$ \\
\hline Três Piedras & $4.43 \pm 0.12$ & $8.85 \pm 0.36$ & $5.34 \pm 0.19$ & $13.15 \pm 0.59$ & $0.033 \pm 0.0004$ & $0.048 \pm 0.0012$ & 98.8 & 90.0 & $1.76 \pm 0.08$ \\
\hline Esteli & $5.46 \pm 0.16$ & $9.60 \pm 0.37$ & $6.38 \pm 0.26$ & $12.28 \pm 0.54$ & $0.036 \pm 0.0005$ & $0.050 \pm 0.0013$ & 91.3 & 86.3 & $1.87 \pm 0.19$ \\
\hline Finca La Pineda & $4.84 \pm 0.19$ & $9.09 \pm 0.52$ & $6.29 \pm 0.29$ & $12.05 \pm 0.72$ & $0.034 \pm 0.0006$ & $0.048 \pm 0.0018$ & 78.8 & 55.0 & $2.09 \pm 0.11$ \\
\hline \multicolumn{10}{|l|}{ Wet zone } \\
\hline San Francisco & $5.06 \pm 0.13$ & $8.91 \pm 0.35$ & $6.38 \pm 0.19$ & $10.80 \pm 0.49$ & $0.035 \pm 0.0004$ & $0.048 \pm 0.0012$ & 90.0 & 71.3 & $1.93 \pm 0.10$ \\
\hline Nueva Guinea & $4.08 \pm 0.12$ & $6.71 \pm 0.33$ & $4.99 \pm 0.20$ & $8.78 \pm 0.41$ & $0.031 \pm 0.0004$ & $0.040 \pm 0.0011$ & 91.3 & 53.8 & $2.16 \pm 0.11$ \\
\hline Dry zone mean & $5.04 \pm 0.20$ & $8.86 \pm 0.24$ & $6.21 \pm 0,23$ & $11.98 \pm 0.36$ & $0.035 \pm 0.0006$ & $0.0474 \pm 0.0009$ & $88.3 \pm 5.1$ & $77.5 \pm 7.4$ & $1.90 \pm 0.05$ \\
\hline Wet zone mean & $4.52 \pm 0.29$ & $8.61 \pm 1.02$ & $5.80 \pm 0.42$ & $11.05 \pm 1.39$ & $0.033 \pm 0.0012$ & $0.0467 \pm 0.0035$ & $87.1 \pm 3.6$ & $63.4 \pm 5.1$ & $2.17 \pm 0.14$ \\
\hline Dry/wet relation & 1.12 & 1.03 & 1.07 & 1.08 & 1.05 & 1.02 & 1.01 & 1.22 & 0.88 \\
\hline General mean & 4.85 & 8.83 & 6.05 & 11.74 & 0.034 & 0.047 & 87.8 & 72.2 & 1.98 \\
\hline \multicolumn{10}{|l|}{ F test } \\
\hline Provenance & $19.2021 * *$ & $52.6559 * *$ & $24.4149 * *$ & $117.1076 * *$ & $2.00^{-4} * *$ & $6.00^{-4} * *$ & 0.0348 & $0.0838 * *$ & $0.2017 * *$ \\
\hline Provenance/zone & $17.3209 * *$ & $60.8767 * *$ & $25.1541 * *$ & $120.8352 * *$ & $1.72^{-4} * *$ & $6.88^{-4} * *$ & 0.0404 & $0.0764 *$ & $0.1148^{\mathrm{a}}$ \\
\hline Error & 3.9541 & 12.2943 & 5.3150 & 24.3117 & $4.47^{-5}$ & $1.39^{-4}$ & 0.0198 & 0.0162 & 0.0355 \\
\hline \multicolumn{10}{|c|}{ Variance components } \\
\hline$\sigma_{p}^{2}$ & 0.2027 & 0.8225 & 0.2700 & 1.7976 & $2.04^{-6}$ & $9.46^{-6}$ & 0.0037 & 0.0169 & 0.0031 \\
\hline$\sigma_{e}^{2}$ & 0.1620 & 0.3190 & 0.0753 & 0.3521 & $1.79^{-6}$ & $3.67^{-6}$ & 0.0198 & 0.0162 & 0 \\
\hline$\sigma_{d}^{2}$ & 1.3980 & 7.6461 & 3.9912 & 17.2700 & $1.47^{-5}$ & $8.8^{-5}$ & -- & -- & 0.0579 \\
\hline$Q_{S T}$ & 0.1150 & 0.0936 & 0.062 & 0.0926 & 0.110 & 0.094 & 0.1589 & 0.5110 & 0.0512 \\
\hline
\end{tabular}
gence among provenances).

${ }^{* *} \mathrm{P}<0.01 ;{ }^{*} \mathrm{P}<0.05$, ${ }^{\text {a }} \mathrm{P}=0.072$. 
variation in 11 C. alliodora provenances, of which seven provenances are common to the present trials (Finca La Fortuna, San Francisco, Esteli, Finca La Pineda, Finca Rincón Alegre, Tres Piedras and Finca El Chilero). Although direct comparison of values with allozymes is problematic, as the quantitative genetic divergence may vary with the age in the same trait and between traits, the trend of high genetic variation within provenances is typical for both quantitative traits and neutral markers in tropical trees. For survival at 23 years of age, $51 \%$ of genetic variation was among provenances, showing the importance of provenance differences to site adaptation and that survival/plantation success can be improved by use of the best provenances.

\section{Correlations between traits and geographic and climatic characteristics}

The standard Spearman correlation coefficient was used to study associations between growth, form and survival traits with geographic and climatic characteristics of the provenance sites. There were no significant correlations between the traits and the geographic and climatic site characteristics of the provenances (Table 3). Genetic correlations among traits measured at five and 23 years of age were low and not statistically significant, indicating that the trees with the best performance at five years of age are not necessarily the best perform- ers at 23 years of age, such that at this site traits at five years of age are not a good predictor of traits at 23 years (Table 4, Figure 1), ruling against early selection in C. alliodora at this site. This is in agreement with ZoBEL and TALBERT's (1984) view that determination of which provenance is the best for a particular environment can only be determined after intensive provenance trials over most of species' rotation. Rotation size is estimated to be at approximately $48 \mathrm{~cm}$ mean d.b.h., taking about 20 years on optimal sites, but likely to be $\geq 50$ years at these suboptimal sites (HERNANDEZ, 1995).

Genetic correlations among traits at the same age were high and statistically significant $(\mathrm{P}<0.01$, Table 4) for all pairs of traits, varying from 0.91 (d.b.h.23 vs vol23) to 1.0 (h vs vol), demonstrating the possibility of indirect selection for one trait based on direct selection for another.

\section{Survival}

At five years of age, survival was relatively high, with a mean of $87.8 \%$ among provenances and ranging from $73.8 \%$ to $98.8 \%$ (Table 2). At 23 years of age survival was moderate having reduced to a mean of $72.2 \%$, ranging from $53.8 \%$ to $91.3 \%$. Dry zone provenances showed higher survival $(77.5 \%)$ than those from the wet zone $(63.4 \%)$, and although the trial sites are similarly dry the reason for the higher survival is unclear. Indeed,

Table 3. - Estimates of the coefficient of Spearman correlation $(r)$ among traits and geographic features of the origins of $C$. alliodora provenances at Luis Antonio Experimental Station, São Paulo, Brazil.

\begin{tabular}{lccccc}
\hline & $\begin{array}{c}\text { Latitude } \\
\text { S }\end{array}$ & $\begin{array}{c}\text { Longitude } \\
\mathrm{W}\end{array}$ & $\begin{array}{c}\text { Altitude } \\
(\mathrm{m})\end{array}$ & $\begin{array}{c}\text { Annual rainfall } \\
(\mathrm{mm})\end{array}$ & $\begin{array}{c}\text { Temperature } \\
{ }^{\circ} \mathrm{C}\end{array}$ \\
\hline h5 & 0.310 & 0.544 & 0.302 & 0.055 & -0.471 \\
H23 & 0.549 & 0.155 & 0.063 & -0.686 & -0.100 \\
d.b.h.5 & 0.581 & 0.619 & 0.270 & -0.055 & -0.511 \\
d.b.h.23 & 0.351 & -0.190 & 0.032 & -0.245 & 0.100 \\
vol5 & -0.032 & 0.366 & 0.032 & 0.032 & -0.032 \\
vol23 & 0.190 & 0.526 & 0.212 & 0.355 & -0.283 \\
sur23 & 0.179 & 0.457 & -0.319 & 0.148 & 0.373 \\
sf23 & 0.182 & -0.214 & -0.176 & -0.699 & 0.118 \\
\hline
\end{tabular}

Table 4. - Estimates of coefficients of genetic correlation $\left(r_{g}\right)$ among the same traits at different ages and among traits in C. alliodora provenances at Luis Antonio Experimental Station, São Paulo, Brazil.

\begin{tabular}{|c|c|c|c|c|c|}
\hline & h23 & d.b.h.5 & d.b.h. 23 & vol5 & vol23 \\
\hline h5 & 0.43 & $0.93 * *$ & --- & $1.00 * *$ & --- \\
\hline h23 & & & $0.91 * *$ & --- & $1.00 * *$ \\
\hline d.b.h.5 & & & 0.33 & $0.95 * *$ & --- \\
\hline d.b.h. 23 & & & & & $0.91 * *$ \\
\hline vol5 & & & & & 0.50 \\
\hline
\end{tabular}

**: $\mathrm{P} \leq 0.01$. 

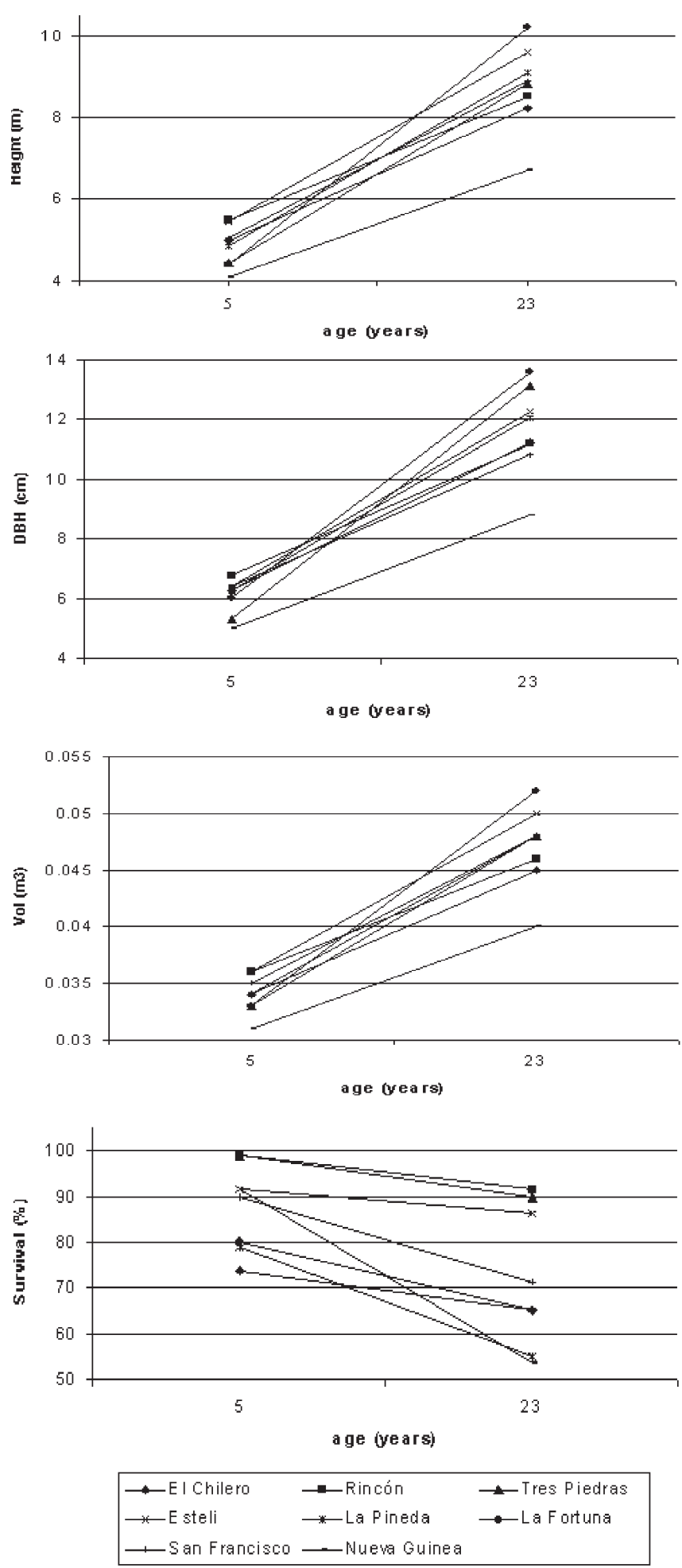

Figure 1. - Provenances height, d.b.h., volume and survival over five and 23 years.

survival of the dry zone provenances was variable with that of two (El Chilero and La Pineda) being low and three (Rincon, Tres Piedras, Esteli) being high.

\section{Height, D.B.H. and volume}

Growth varied among provenances over the period of study (Table 2, Figure 1). At five years of age, the best provenance for height, d.b.h. and volume was Rincon
Alegre followed by Esteli, with the worst being Nueva Guinea. At 23 years of age performance changed to some extent with the best provenance for height, d.b.h. and volume being Finca La Fortuna, followed by Esteli for height and volume and Tres Piedras for d.b.h., with the worst still being Nueva Guinea. The relative difference between the best and worst provenances for height, d.b.h. and volume at 23 years of age were $34.3 \%, 35.3 \%$ and $23 \%$, respectively.

Observations of growth in provenance trials of C. alliodora revealed clear differences between provenances from dry and wet zones (BosHIER and HENSON, 1997). In Costa Rica, provenances from drier regions germinated more quickly and showed quicker growth rates than the wet zone provenances over the first six months in the nursery (BosHIER, 1984). However, after one year in the field the wet zone provenances showed the best growth. In nine of the 12 provenance tests established at various sites in other tropical countries (Costa Rica, Colombia, Fiji, Solomon Islands, Ivory Coast, Liberia, Ghana and Nigeria), the best growth was shown by wet zone provenances (BosHIER and HENSON, 1997). In contrast at the sub-tropical Luiz Antonio site at 23 years of age dry zone provenances tend to grow more quickly, although the best provenance was from the wet zone (Finca La Fortuna), as was the worst (Nueva Guinea). The relative height and d.b.h. growth of dry zone provenances were 2.3 and $7.8 \%$, respectively, higher than the wet zone provenances, suggesting poorer capacity to adapt to trial site conditions that are markedly drier and colder than the wet zone provenances encounter naturally.

Based on a comparison of the $C$. alliodora provenances' mean height $(8.83 \mathrm{~m})$, d.b.h. $(11.74 \mathrm{~cm})$ and volume $\left(0.047 \mathrm{~m}^{3} /\right.$ tree $)$ at 23 years of age with the growth at the same experimental site of a Brazilian tropical tree, Cariniana legalis (SEBBENN et al., 2002) at 17 years (height $=12.26 \mathrm{~m}$; d.b.h. $=13.49 \mathrm{~cm} ;$ vol $=0.23 \mathrm{~m}^{3} /$ tree), C. alliodora has slow growth and low silvicultural potential at this site. Futhermore, comparing C. alliodora's growth with that of the exotic conifer Araucaria cunninghamii (SEBBENN et al., 2005) after 20 years at the same site (height $=19.68 \mathrm{~m}$; d.b.h. $=19.25 \mathrm{~cm}$ ), reinforces the view of $C$. alliodora's very slow growth at this site and that it is not the most appropriate species for commercial timber reforestation in the Luiz Antonio region. According to YARED (1983), the best climatic conditions for C. alliodora's growth are those with moderate to high annual rainfall and mean temperature $(2,000$ to $5,000 \mathrm{~mm}$ and $24^{\circ} \mathrm{C}$, respectively). Although the Luiz Antonio region has fertile soils (latosol) and annual mean temperature about $24^{\circ} \mathrm{C}$, frosts are not uncommon and temperatures of $2-3{ }^{\circ} \mathrm{C}$ occur regularly during the coldest months of the year. In the natural distribution of these Central American provenances temperatures rarely fall below $10^{\circ} \mathrm{C}$, and it seems likely the much lower minimum temperatures than those normally experienced by the tropical provenances under test, led to the species being under physiological stress and the subsequent poor growth.

The La Fortuna provenance showed the best stem form (Table 2), followed by San Francisco and Rincon 
Table 5. - Estimates of expected gains with a mass selection of $34 \%$ of the best trees for the traits height, d.b.h., and volume and stem form at the age of 23 years for C. alliodora.

\begin{tabular}{|c|c|c|c|c|c|}
\hline \multirow[b]{2}{*}{ Provenance } & \multicolumn{4}{|c|}{ Ranking of provenances } & \multirow{2}{*}{$\begin{array}{c}\text { Number } \\
\text { of selected } \\
\text { trees }\end{array}$} \\
\hline & $\begin{array}{l}\text { height } \\
\text { (m) }\end{array}$ & d.b.h. $(\mathrm{cm})$ & $\begin{array}{c}\text { volume } \\
\left(\mathrm{m}^{3} / \text { tree }\right)\end{array}$ & $\begin{array}{l}\text { stem } \\
\text { form }\end{array}$ & \\
\hline Finca El Chilero (Guatemala) & $7^{\circ}$ & $5^{\circ}$ & $7^{\circ}$ & $6^{\circ}$ & 1 \\
\hline Finca Rincón Alegre (Guatemala) & $6^{\circ}$ & $6^{\circ}$ & $6^{\circ}$ & $4^{\circ}$ & 2 \\
\hline Tres Piedras (Honduras) & $5^{\circ}$ & $2^{\circ}$ & $3^{\circ}$ & $8^{\circ}$ & 40 \\
\hline Esteli (Nicaragua) & $2^{\circ}$ & $3^{\circ}$ & $2^{\circ}$ & $7^{\circ}$ & 40 \\
\hline Finca La Pineda (Nicaragua) & $3^{\circ}$ & $4^{\circ}$ & $4^{\circ}$ & $3^{\circ}$ & 15 \\
\hline Finca La Fortuna (Honduras) & $1^{\circ}$ & $1^{\circ}$ & $1^{\circ}$ & $1^{\circ}$ & 51 \\
\hline San Francisco La Ceiba (Honduras) & $4^{\circ}$ & $7^{\circ}$ & $5^{\circ}$ & $5^{\circ}$ & 1 \\
\hline Nueva Guinea (Nicaragua) & $8^{\circ}$ & $8^{\circ}$ & $8^{\circ}$ & $2^{\circ}$ & 0 \\
\hline Total & & & & & 150 \\
\hline Mean of traits in original population $-\bar{x}_{o}$ & 8.78 & 11.79 & 0.047 & 1.38 & \\
\hline Mean of trait in selected population $-\bar{x}_{s}$ & 11.05 & 15.03 & 0.055 & 1.46 & \\
\hline Expected gains by massal selection - $G S$ & 1.59 & 1.59 & 0.003 & 0.03 & \\
\hline Mean of trait in improved population $-\bar{x}_{i m p}$ & 10.37 & 13.3 & 0.050 & 1.41 & \\
\hline Expected gains by massal selection - $G S(\%)$ & 18.11 & 13.47 & 5.48 & 1.96 & \\
\hline
\end{tabular}

\begin{abstract}
Alegre, while the Tres Piedras provenance had the worst stem form. The two provenances with the best stem form originate from wet zones and in general stem form of the wet zones provenances (2.17) was statistically better than those from dry zones (1.90). The San Francisco and Nueva Guinea provenances also showed the best stem form in the other international provenance trial sites around the tropics (Boshier and Henson, 1997). According to CHASE et al. (1995), the most impressive specimens of $C$. alliodora are found in lowlands of moderate to high rainfall, where trees can reach $40 \mathrm{~m}$ in height and over $80 \mathrm{~cm}$ in d.b.h.. In the dry regions the trees are generally small (10-15 $\mathrm{m}$ in height) and of poor form.
\end{abstract}

\section{Tree breeding}

Although the trial showed that the trialed C. alliodora germplasm is not the best option for timber reforestation in the Luiz Antonio region, the results indicated large genetic variation among zones and provenances within zones and thus the possibility of improvement by selection of the most productive provenances and trees within provenances. Further testing of local provenances may show the species to have good silvicultural potential in São Paulo state, and other states of Brazil.

The analysis of selection to improve stem form and growth illustrates the potential for improvement through transformation of the trial to a seedling seed orchard, with a wide genetic base (Table 5). By selecting the best trees in seven of the eight tested provenances, excluding the worst performer (Nueva Guinea), gains of $18 \%$ (height), $13 \%$ (d.b.h.), $5 \%$ (volume) and $2 \%$ (stem form) can be expected in 23-year-old stands of the species, planted in areas with the same environmental characteristics as Luiz Antonio. A larger number of trees would be selected in the best provenances, e.g. 51 from La Fortuna, the best provenance, with only one or two trees from the worst provenances, (Finca El Chilero, Rincón Alegre and San Francisco). Thus, on random mating, gene frequencies of the improved population are expected to be determined principally by those of the best provenances. Such gains would depend on there being no outbreeding depression as a result of mating across populations.

\section{Acknowledgements}

The authors are grateful to the Oxford Forestry Institute, particularly to JUSTIN W. STEAD, for providing the seeds for this trial. The author A.M.S would like to thank the Conselho National of Desenvolvimento Científico e Tecnológico $(\mathrm{CNPq})$ for granting him a scholarship for Achievements in Research. The authors would also like to thank two anonymous referees for constructive comments.

\section{References}

Boshier, D. H. (1984): The international provenance trial of Cordia alliodora ( $\mathrm{R} \& \mathrm{P}$ ) Oken in Costa Rica. In: Provenance and genetic improvement strategies in tropical forest trees. Mature, Zimbabwe, April 1984. Barnes, R. D., Gibson, G. L. (Eds). Commonwealth Forestry Institute, Oxford, and Forest Research Center, Harare. p. 168-185.

Boshier, D. H. and J. F. MesÉn (1987): Availability of seed of Cordia alliodora (R. \& P.) for progeny testing. Forest Genetic Resources Information No. 15, FAO, Rome, 30-35.

Boshier, D. H. and M. Henson (1997): Genetic Variation. In: Cordia alliodora: genetics and tree improvement. Boshier, D. H., LAmb, A. T. (Eds). Tropical Forestry Papers No. 36. Oxford Forestry Institute, Oxford. 39-65.

Boshier, D. H., M. R. Chase and K. S. Bawa (1995): Population genetics of Cordia alliodora (Boraginaceae), a neotropical tree. 2. Mating system. American Journal of Botany 82: 476-483.

Chase, M. R., D. H. Boshier and K. S. BawA (1995): Population genetic of Cordia alliodora (Boraginaceae), a neotropical tree. 1. Genetic variation in natural populations. American Journal of Botany 82: 468-475. 
GIBBS, P. E. and N. TARODA (1983): Heterostily in the Cordia alliodora - C. trichotoma complex in Brazil. Revista Brasileira de Botânica 6: 3-10.

Greaves, A. and McCARTER, P. S. (1990): Cordia alliodora: a promising tree for tropical agroforestry. Tropical Forestry Papers 22. Oxford Forestry Institute, Oxford, UK. 37 p.

HERNANDEZ, G. O. R. (1995): Rendimiento y analisis financiero del sistema agroforestal café (Coffea arabica cv Caturra) con poro (Erythrina poeppigiana) bajo diferentes densidades de laurel (Cordia alliodora). Unpublished M. S. Thesis. CATIE, Turrialba, Costa Rica. 70 p.

Hummel, S. (2001): Una especie nativa en plantaciones: Cordia alliodora. OIMT Actualidad Forestal Tropical 9/3. http://www.itto.or.jp/live/Live_Server/128/ tfu.2001.03(18).s.pdf.

Liegel, L. H. and J. W. Stead (1990): Cordia alliodora (Ruiz \& Pav.) Oken. Laurel capá prieto. In: Russel, M., Honkala, B. H. (eds). Silvics of North America: 2. Hardwoods. Agric. Handb. 654. Washington, DC: US. Department of Agriculture, Forest Service: 270-277.

RESENDE, M. D. V. (2002): Genética biométrica e estatística no melhoramento de plantas perenes. Brasília, DF, Embrapa Informação Tecnológica, 975p.

S.A.S. (1989): Institute Inc. SAS Procedures Guide. Version 8 (TSMO). SAS Institute Inc. Cary, N.C., 27513, USA.

Sebbenn, A. M., P. Y. Kageyama and A. C. S. Zanatto (2002): Estimativas de ganhos genéticos na seleção em populações de Cariniana legalis (Mart.) O. Ktze, incorporando informações do sistema misto de reprodução. Revista do Instituto Florestal 14: 65-77.

Sebbenn, A. M. S., A. C. S. Zanatto, M. L. M. Freitas, A. S. SATO and L. C. EtTori (2005): Genetic variation in Araucaria cunninghamii provenances in Luiz AntonioSP, Brazil. Crop Breeding and Applied Biotechnology 4: $1-8$.

SomArRIBA, E. and J. W. Beer (1987): Dimensions, volumes, and growth of Cordia alliodora in agroforestry systems. Forest Ecology and Management 18: 113-126.

StEAD, J. W. (1980): Commonwealth Forestry Institute international provenance trial of Cordia alliodora (R. \& P.) Oken. Eleventh Commonwealth Forestry Conference, Trinidad and Tobago and Jamaica, September, 17p.

Ventura, A., G. Berengut and M. A. M. Victor (1965/1966): Características edafoclimáticas das dependências do Serviço Florestal do Estado de São Paulo. Silvicultura 4: 57-139.

YARED, J. A. G. (1983): Comportamento e variabilidade de procedências de Cordia alliodora (Ruiz \& Pav.) Oken, no planalto do Tapajós - Beltera-PA. Unpublished thesis, Universidade de São Paulo (ESALQ/USP), Piracicaba-SP. 108 p.

Zobel, B. and J. TALBert (1984): Applied forest tree improvement. Copyright by John Wiley \& Sons Inc. New York. 496p.

\title{
Genetic Variation and Climatic Impacts on Survival and Growth of White Spruce in Alberta, Canada
}

\author{
By D. M. RweyongezA ${ }^{1), 2)}$, R.-C. YANG ${ }^{2)}$, N. K. DhiR ${ }^{3)}$, L. K. BARNHARDT ${ }^{3)}$ and C. HANSEN ${ }^{3)}$
}

(Received $15^{\text {th }}$ February 2006)

\begin{abstract}
Because climate has the greatest effect in determining the genetic structure of forest tree species, climatic variables with large effects on growth and survival need to be identified. This would enable proper matching of tree populations to planting sites in the present and future climates. We analysed 24-year survival (S24), height (H24) and diameter (D24) from a series of white spruce provenance trials with 46 populations and 8 test sites in Alberta, Canada. We determined: (1) the amount and pattern of genetic variation, (2) the response of populations to climatic transfer and (3) the potential effects of climate change (2030-2039) on H24 and S24 of the

1) Corresponding author: Deogratias M. Rweyongeza. Tel. 780422-5436, Fax: 780-427-0084. Email: drweyong@ualberta.ca

2) Department of Agricultural, Food and Nutritional Science University of Alberta, Edmonton, AB, Canada, T6G 2P5.

$\left.{ }^{3}\right)$ Alberta Tree Improvement and Seed Centre, Alberta Sustainable Resource Development, Smoky Lake, AB, Canada, T0A $3 \mathrm{C} 0$.
\end{abstract}

species in Alberta. We found that: (1) using the intraclass correlation, the between-population genetic variance was $10.6 \%(\mathrm{H} 24)$ and $6.6 \%$ (D24) of the betweenpopulation phenotypic variance across sites, (2) three climatic white spruce regions exist in Alberta within which variation in growth potential is strongly clinal, (3) the annual moisture index (AMI) expressed as a ratio of degree days above $5^{\circ} \mathrm{C}$ (GDD) and mean annual precipitation (MAP) was the major determinant of survival and growth at the test sites, (4) we found that at the level of AMI predicted for the 2030-2039 period, survival and growth would decline substantially in the continental part (northern and central) of Alberta where drought already exists. However, during the same period, survival and growth would increase substantially in the foothills and Rocky Mountains region where growth is currently limited by low GDD due to a short growing season.

Key words: climate change, moisture index, Picea glauca, provenance trial, response function. 